\title{
BCHIRA BEN MRAD: A PIONEER FEMINIST (1913-1993)
}

Khedija Arfaoui ${ }^{*}$ 凹 iD

${ }^{* 1}$ President of the Muslim Union of Tunisian Women, Tunisia

DOI: https://doi.org/10.29121/granthaalayah.v8.i8.2020.1058

Article Type: Research Article

Article Citation: Khedija Arfaoui. (2020). BCHIRA BEN MRAD: A PIONEER FEMINIST (1913-1993). International Journal of Research GRANTHAALAYAH, 8(8), 302-318. https://doi.org/10.29121/granthaa layah.v8.i8.2020.1058

Received Date: 10 August 2020

Accepted Date: 31 August 2020

Keywords:

Women

Feminist Movement

Feminism

Women's Rights

Education

Islam

Code of Personal Status

Emancipation

Culture

Freedom

\begin{abstract}
Can one understand the present without knowing the past? Isn't life a continuation of the past and doesn't the present owe many of its characteristics to the past? Asking these questions helps one to figure out how women who lived in a secluded and closed environment were able to break the walls that separated them from the public sphere. It is thus that we come to realize and understand how Bchira Ben Mrad's (from now on: BBM) initiative in the early 1930s did not start from nowhere but had its origins in the women's past of her country.
\end{abstract}

\section{INTRODUCTION}

\section{Early resistance of Tunisian women}

"And what if Tunisia had always been "feminist"? This thesis makes it possible in particular to explain that the Code of Personal Status, adopted in 1956, became the custom so easily" (Fawzia Zouari, 56)

\subsection{A BACKGROUND OF STRONG WOMEN LEADERS}

Bchira Ben Mrad had a host of prominent female figures who have shown courage, resistance and pride, and who inspired her activism. A few examples are worth considering for they show women who went beyond the limits

1 (French text) Et si la Tunisie était « féministe » depuis toujours ? Cette thèse permet notamment d'expliquer que le Code du statut personnel, adopté en 1956 à l'initiative de Habib Bourguiba, soit entré dans les mœurs avec autant de facilité.

(c) 2020 The Author(s). This is an open access article distributed under the terms of the Creative Commons Attribution License, which permits unrestricted use, distribution, and reproduction in any medium, provided the original author and source are credited. 
imposed on them by culture, traditions and religion, breaking taboos and leaving their names in history. For, Tunisian women were saints and priestesses and held important religious duties, hence "the cult of Tanit, a Carthaginian and Phoenician Goddess, still survives today in the Tunisian women's memory and behavior" (Zouari, 56). Several Carthaginian goddesses were represented holding parchments, showing that even in bygone days, Tunisian women had an education. In the $9^{\text {th }}$ century B.C., Dido, also known as Elyssa, came from Phoenicia and became the queen of Carthage. At a time when history and legend mixed, even in the Christian era, Saint Perpetua, first female writer, was a patron saint for mothers and wives. At the end of the 600s, Amazigh El Kahena bravely and victoriously ruled tribes during thirty-five years: a distinguished resistant to the Arab-Muslim conquest, she gloriously defeated Hassan Ibn Nooman's Arab troups and chased them as far as Gabes, in Tunisia. Betrayed by her own people, she found refuge in El Djem where she was finally captured and decapitated, her head offered to the caliph Abdelmalek in Syria. The name El Kahena-which means the person who knows what is going to happen-was given to her by the Arabs. Her origin is not clear: some say she was from a Byzantine descent, others that she was a Jew. Whatever her creed, she did not fight in the name of religion, but in defense of her native land and for her people.

In the $9^{\text {th }}$ century, Fatima el-Fehria from Kairouan founded the famous mosque of the Karawiyyine, in Fez, Morocco. Saida Manoubia, (1180-1257) is another case, for she dared enter another forbidden world for women: that of religion and also of men. How did she manage to be admitted in that world? She had studied the Qur'an and became a well-known and respected saint. Very well-read, she had a strong personality and spent her life helping the poor and the homeless. She was rewarded by an honorific title that has been conferred to no other woman: she became the head of all imams, and imams were all males! She worked to earn a living, refusing marriage and economic dependency, never accepting any financial help from anyone. Her popularity, her charisma and her beauty were such that she overcame criticisms. She was respected and loved to the end. Hence the sanctuary built under her name (Zouari, 57). Princess Aziza Uthmana 1606-1669), the grand-daughter of the governor of Tunis, Uthman Dey, and first wife of Hamouda Pacha, Bey of Tunis (1631-1666) freed her slaves before even Tunisia abolished slavery in 1846, and gave her fortune to charitable works. She also paid for the freedom of people held as prisoners. She provided for poor girls the means to get married and founded a hospital that still bears her name in the Kasbah of Tunis (Tchaicha and Arfaoui, 15).

These women leaders and many others were bound to leave an impact and serve as examples to follow in order to bring changes in the status of women.

\section{IMPACT OF 19TH CENTURY WAY OF LIVING ON BCHIRA BEN MRAD}

Like the rest of the Arab world, Tunisia had eras of greatness, prosperity and progress. In the $19^{\text {th }}$ century, there already was a general trend among reformers that girls' education was fundamental to the development of the country and that illiteracy was the main cause of their underdevelopment (Zangar). The founding fathers of this reformist trend, scholars like Abdelaziz Thaalbi, Hedi Sebaî and others were keen on learning about other countries, in the Arab world as well as in the West and they read what was written there. They were set on fighting illiteracy and ignorance as declared by Mahmoud Kabadou (1812-1871), a scholar of Quranic Studies and a professor at Zeituna Mosque (Chammam, 6). They expressed their belief that the Qur'an never was against girls' education but that it made for an equal right to education for both sexes. Like Kacem Amin in Egypt, Tahar Haddad who in 1930, wrote Our Women in the Shari 'a and Society "و والمجتمع الثّريعة في امر أنتا ", and Habib Bourguiba later on, they justified the reforms they were putting forth by using the Qur'an itself.

If we consider women with the feeling that they are inferior, without taking into account their humility and social forfeiture, such an attitude can be but one aspect of our ignorance of ourselves and a proof that we are accepting our humility as well as our forfeiture. If we sincerely love and respect women, we have to strive to improve their personalities: that would be a sign of self-respect on our part. (Tahar Haddad, 15)

While modernist trends were thus spreading all over the Arab world, reports show $19^{\text {th }}$ century women still living under a patriarchal system in which the father was head of the household, imposing his rule on the entire family. The Muslim family was conservative and traditional particularly in urban areas for in rural areas women could find seasonal work harvesting or olive-cropping, with their husbands: they would not have been able to work if veiled. But, until the fifties, "most Tunisians still believed women's education was a form of religious heterodoxy" (Secrétariat d'Etat à l'Information, 7). "Adamant, devout conservatives, would close their ears and ask God's 
forgiveness whenever they were told about modernization," de Montety2 wrote. "Women who dared challenge this system by refusing the authority that curtailed their freedom to choose the man they wished to marry, for example, or who complained of a husband's lack of consideration, could be sent to Dar Jaoued, a place where disobedient daughters and wives were placed to preserve the family's honor, until they learned to obey the social rules imposed on them (total obedience to father and husband), which only the Code of Personal Status (CPS) ${ }^{3}$ put an end to in 1956. No court decision was needed for a man to send a disobedient wife or daughter there (Largueche, 1991).

Repudiation and unilateral divorce were a major cause of concern and left women helpless. In fact, it was dependency that made women accept their fate because they did not want to live with the stigma of being divorcees. As to polygamy, even though legal, it was far from being general. Indeed, very few men had more than one wife. At most, a man could marry several times, but seldom with more than one wife at a time. In an interview, BBM said she was against polygamy. Women are the first to be concerned about the issue. She said that women should not accept to marry a man who is already married. Those who do have their dignity and humanity trampled upon (Nissa, 14). The family was managed and controlled by the head of the family: the father. All decisions were taken by him. That was the fabric of life in Tunisia in the 19th century and in the rest of the Maghreb and it continued although less and less strictly, well into the twentieth century. In spite of that, BBM thought that women had to defend their rights in order to play a role in society. Lack of education was not particular to girls though, for fathers also privileged their youngest sons whom they allowed to have an education at the expense of the eldest who had to quit school and help them run the family's business or farming and their schooling was therefore limited to the kuteb, a place where children learned the Qur'an (the practice is still relevant today, this being an easy way to have one's children memorize the Qur'an) under the guidance of a tutor; they also had a primary education.

Those of the girls who were lucky to have an open-minded father had a primary education while religious education was fairly general, even if purely oral. In such a context, the world of men being closed to them, girls were trained in home economics, helping their overworked mother take care of her too many children. Girls' education was a primary concern for both men and women making for the creation of a private school for Muslim girls at the end of the $19^{\text {th }}$ century, close to Bab Souika. In 1904, Abdelaziz Thaalbi declared "It is imperative that Tunisian women enjoy their rights and take what is rightfully theirs in life..." (Chammam, 7-9). There had been a few schools for girls, mainly for Christian and Jewish girls, with some Muslim girls belonging to the elite. Several institutions had been founded by missionaries. Known first as the Millet School because it was headed by Louise Renée Millet, the wife of the French General Resident, the Rue du Pacha School was the first non-missionary school for girls with a modern curriculum. It was founded on 1 May 19005. Miss Zobeida Amira was its first Tunisian principal. In 1957, it became the Rue du Pacha Girls' Secondary School. The first women that were to play a role in women's emancipation came out from that historical school. BBM was one of them. There were very few pupils at first, belonging to the middle-class but their numbers increased with time. They were veiled and never walked to/from school unaccompanied. They could not be seen from outside the school walls and had their meals brought to them so as to avoid being in the streets too often. Girls' national education started then, albeit on a small scale. That education represented an asset even though short for it provided girls with the guarantee of finding a husband in the well-todo society. From this, one can see that education gave girls a value, one that many wanted to have. Men did not expect more education, believing that it was enough for a woman to be able to read and write, help her children eventually do their homework and they took pride in that. The "Certificat d'études" obtained at the end of primary education was so important for both boys and girls that many had it proudly framed and hung in the living-room or place of work for everyone to see. In fact, many a girl was quite an artist in the embroidery sector. Girls either worked at home or their mother would have them go to a teacher's (Mâalma) in the field and learn the basics of sewing and embroidering. They knew that what was lurking on the horizon for them was marriage and they usually married quite young. BBM was 17 when she married. On her wedding day, her nephew Moez Karoui reports, she had a last glance at her desk and asked her youngest sister, Om Heni, to keep everything as they were and not to touch anything. She wanted to find everything as she had left them whenever she would come on a visit. She loved her sisters so

\footnotetext{
2 “Femmes de Tunisie," pp. 84 and 92. Cited in Secrétariat d'Etat à l'Information, p. 8.

${ }^{3}$ The CPS abolished repudiation, divorce, polygamy. It also set up a minimum age for marriage and made for the consent of both the bride and groom for marriage to take place.

${ }^{4}$ In 1966, Tunisia launched a successful family planning program.

${ }^{5}$ Bchira was 9 when she joined that school together with her sisters and cousins. She had to leave one year later as ordered by her uncle, Neji Ben Mrad, who did not approve of girls' education.

International Journal of Research -GRANTHAALAYAH 
much she believed she would come back as often as she wished, which she definitely did for her husband never disapproved with what she was doing. When she married, she knew nothing about marriage or men. Her life was limited to her family circle and centered on learning the Qur'an and reading. Sheikh Mohamed Salah Ben Mrad would not let his daughters stay in the company of other women for he did not want them to listen to their conversations. Only his mother had this privilege. BBM married Salah Zahar, a man she had not even ever heard about; neither did she know anything about his family. But, she reported, he was very kind and loving and so was his mother. He would spoil her, offering her expensive presents. She liked to spend summers at her father's houses, with her husband's full consent for he never objected to that. She really had nothing to complain about. However, BBM expressed her sadness at not having had any children, confessing that she had had many abortions because she had married too young. Childlessness, however, probably allowed her to find the time to have activities outside of the home.

Hence, BBM moved from her father's authority to that of her husband, becoming the spouse of a man she had not chosen but one her father had wanted her to marry. Very often, a girl would be "promised" to a cousin or to the son of a friend of her father. The practice of marrying a cousin was quite common throughout the country for it had advantages: it strengthened family ties, although it often caused the birth of children with physical disabilities, but it also allowed property to remain within the family and not fall into the hands of strangers. If not so, there were women known as matchmakers who would visit families with daughters to marry, with photos of a young man looking for a bride, and they might also be given a photo of the girl so that the groom-to-be could see what the girl looked like. Many marriages took place through the work of those matchmakers. That was the way girls lived, with no expectations but marriage, then motherhood and a way of life no different from that of their mothers. For their future was to be wives and mothers, entirely dependent on men. They were to procreate and preferably give birth to sons, so as to ensure that the father's name would remain whereas a girl would give children who would have their father's name. This trend was to weaken with time, particularly after independence, with a change towards marriage and family life (Mahfoudh-Draoui).

\section{19 ${ }^{\text {TH }}$ CENTURY TUNISIAN WOMEN TAKE ACTION}

What was women's place in the family in the $19^{\text {th }}$ century? The $19^{\text {th }}$ century was an era of reforms proposed by a number of scholars who were open to other cultures and ideas. It was marked by the promulgation of the Fundamental Pact (Ahd-al-Aman) in 1857 by Ahmed Bey that made for equality of all citizens, Muslim, Christian and Jews, independently of their religion. It was the first in the Arab world and in Africa. It paved the way for independence from the Ottoman Empire (1881, with the establishment of the French protectorate) and a passage to modernity. This Pact was followed by the short-lived first Constitution in the Arab world in 1859. Ideas of freedom and equality of rights were in the air and were bound to have an impact. Yet, women remained cloistered in the home and so, the question one may ask: how could their voices be heard in such a closed world? Women lived in a strict patriarchal world with a clear division between the sexes and the absence of women in the public sphere was a fact. For, "Islamic family law regulated family life in Tunisia. Islamic family law places women in a subordinate status by giving power over women to men as husbands and as male kin (Charrad, 28). How could one find information about women's private lives at the time that preceded independence?

Dalenda Largueche found the answer by turning to the Court Houses throughout the country. Indeed, there she could find clear information about family life and relations between women and men within the family, even very intimate ones on their very sexuality. Thus is one able to discover "a female identity, complex and plural" through "the court of justice as a space of the fabric of women's identity and gender regulation" (Larguèche, 143). Shari'a courts and notary records thus give researchers an abundance of information about women and the family. The women that emerge from this data appear as resistant to injustices that curtailed their personhood and dared go to court to demand justice through Shari'a. In spite of the gendered fabric of life, several of the plaintiffs obtained satisfaction. Women could complain of the sexual impotence of their husband and obtain, after proof of the fact, separation and divorce. In some instances, a woman could decide about her own marriage without the consent of her father/tutor, be she a virgin or previously married. A woman could obtain divorce provided she gave her husband "a compensation payment" (Larguèche, 144). At least, that was a way of freeing oneself from a marriage relationship one does not like. This practice was not rare in the country. Marriage contracts are also important revelators of women's authority in marriage, since they allowed women to impose monogamy: more than a thousand years ago, in the $9^{\text {th }}$ century, a unique contract, Al-çadâq al-qayrawânî, sealed the wedding of Abu Jaafar Al Mansour, 
Bchira Ben Mrad: A Pioneer Feminist (1913-1993)

a powerful Abbasid Caliph and Arwa Al Himayariya. The latter had accepted to marry him under the condition that monogamy should be specified in her wedding contract, establishing thus monogamy for the first time in the Arab world. That contract gave a woman the power to repudiate her husband and put an end to her marriage relationship should he marry a second wife or have a concubine. If the Qur'an recognizes polygamy, it does not recommend it though: indeed, it allows up to four wives but under the condition that they be treated equally. But, is it possible to treat four wives equally? Therefore, a man should have but one wife. This Kairouan contract is an expression of women's awareness and desire to abolish laws and rules that were detrimental to their dignity, happiness and wellbeing. To get married, a woman needed a tutor, but she was the only one to take the decision to divorce. This legal formidable step forward demonstrates the will of enlightened jurists of the time to protect their daughters and women against polygamous marriages (Boukhris, 6-7). It is interesting to note that this wedding contract was to facilitate the abolition of polygamy in the CPS in 1956 for it did not come about as something completely new: it had, indeed, a historic precedent! These and other records are enough to reveal women's awareness of their rights and of their resistance to violence against their personhood and dignity as well as their legitimate desire to be happy in every sense of the word. In 1876, a girl from Kairouan petitioned the court against her brother who had her marry against her will. She obtained her divorce (Larguèche, 145).

Did all women go to courts though? For this is a question to ask when we know how closed-in the Muslim family used to be. According to court records, women from the notability did not for a question of respectability in order not to harm the family's reputation. Those that did had a lower class status (Largèche, 149). Through the courts, private life became public and it is not surprising that these private lives' stories left marks among women in the late $19^{\text {th }}$ and early $20^{\text {th }}$ centuries.

\section{WOMEN'S STATUS IN THE 1920S AND $1930 S$}

\section{"A woman is traditionally submitted to her father, then to her brother, then to her husband who, himself obeys his father" (Vincent: 4)}

Women were certainly respected while carrying out their duties as housewives and mothers. They took care of the family while the husband provided for their needs. True, the husband's authority ruled their lives and some women might have experienced some forms of frustrations and violence, but they had their dignity preserved and their voice would be heard whenever needed. Resistance against the colonizer was a good opportunity for some women to offer their services and thus, gain some liberty and visibility in the process. They did not manage their efforts to achieve that. Mahfoudh-Draoui gives a few names such as: Hallouma Mallouli 1903 from Ras Jbel, Khadija Rabeh 1910 from Metouia, Mabrouka Gasmi 1909 from Nefza, Khedija ben Ali 1907 from Douz, Cherifa Fayech 1906 from Metouia, BBM 1913 from Tunis, HalimaTriki 1916 from Agereb, chedlia Bouzgarrou 1917 from Tunis, Cladys Adda 1921 from Gabes, Fatma Enneifar 1920 from Jebel Bou Hadma, Wassila ben Saida 1930 from Sfax, etc. These names are significant because they show that women's awakening to the necessity to take part in social and political activities was not limited to one region but that it was prevalent throughout the country. With the support of a close relative, generally the father or brother, these early activists joined the resistance movement and were thus able to put a foot in the outer world, traditionally closed to them.

BBM, who is the subject of this article, was one of many women throughout the country that dared emerge in that world of men and mark their presence for the welfare of their country. Several have remained anonymous, but a few have been able to act and make their voice heard. BBM lived in a well-off, harmonious family environment with a loving father who provided everything for his daughters' comfort and happiness. Haddad reports on how Islam fought against the "superstitious disdain" Arabs felt about daughters but, he asked: "hadn't Prophet Mohamed declared: 'I am the father of girls'?" For the Prophet wanted his daughters to be loved (Haddad, 27). Sheikh Ben Mrad felt the same way towards his daughters. Growing up with such a loving father, allowed BBM to be able to act and bring changes in her life and in those of other women in spite of the fact she was hardly ten at her mother's death. She was a feminist activist as she liked to claim. Profoundly Muslim and very well-read as well as well-travelled, in particular she visited France and Eastern Europe (Russia, Poland and Romania) where she could admire women at work (Karoui). She combined good morals and piety with learning and like others in that period she made good and strong use of these two issues in her combat for improving other women's lives. This was in accordance with the mentality of the time that required "proper behavior" on the part of women: "Preoccupation with female purity and modesty is at the center of the social norms governing gender relations in the Middle East... Women thus carry a 
large share of the burden for safeguarding the family lineage and tribal honor" (Charrad, 62-63). Growing modernization was beginning to change the fabric of life, but it was still managed by a strong patriarchal system. An uncle, a grand-father could watch over a girl' life and make her leave school. BBM's uncle tried to do that but she was lucky because her father would not listen to his advice, set as he was on giving his daughters an education that would serve them in their life.

Still, BBM lived in an age when women led a secluded life, under close scrutiny on the part of the male members of their family, but also of mothers, grandmothers, aunts who watched over young girls very severely. Wassilla Ben Ammar, Habib Bourguiba's second wife, said about life then that going out without a veil for a girl meant she wouldn't find a husband. It was even worse if a woman recognized a man in the street (Vincent, 6). A girl might receive visits from Christian or Jewish female friends, but she would not be allowed to go and visit them! She could also see that the latter led much freer lives and wish she could be as free as them. A few had private tutors to learn the basics of Arabic and mostly the Qur'an. She could listen to the radio, if she was allowed to for a brother might decide that it was not good for her: wouldn't it make her want to imitate the Western girls and ladies she could see from her windows? Rare were those who had the opportunity to travel and Wassila Ben Ammar was one of them. She went to France in 1929, without anyone to escort her, without a veil, and was even able to swim in a swimming-suit! (Vincent, 6). BBM belonged to the same generation, therefore, she was aware of women's gradual emancipation; she knew about the existence of the women of the past depicted in the first part of this article who had managed to be strong in spite of cultural and religious taboos. She was also aware of the discriminations against women. That awareness gave her the sense of initiative that allowed her to become the leader of the women's renaissance in Tunisia as suggested by the title of Mahmoud Chemmam's book, "Bchira Ben Mrad, the leader of the feminist movement in Tunisia" (Bchira Ben Mrad, Zaîmatu el Nahdha el nissaîya bitunis). In the $19^{\text {th }}$ and early $20^{\text {th }}$ centuries, women were hardly visible, as their lives were severely controlled by social, religious and cultural norms. One may wonder how a feminist movement could have emerged in those circumstances. However, current events taking place throughout the country had paved the way for this formidable event to take place (Arfaoui, 2007). Indeed, looking back into history, one finds out that, despite their utter dependency on men, even in the $19^{\text {th }}$ century, there had been women who had sued father, brother or husband and obtained satisfaction in spite of male domination and of the fact that their lives were controlled by shari'a law. Thus, a woman could sue her father for making her marry against her will, obtain a divorce if/when her husband was declared sexually impotant. Such cases, and they were frequent, could not be ignored and thus one can easily deduct that they were the seeds of the feminism that BBM was to espouse and work for.

In those decades that marked the early $20^{\text {th }}$ century, Tunisian women lived in the intimacy of their home. Their world was thus, concentrated on reading the Qur'an, housework, cooking, breast-feeding, socializing children, sewing... Men came in and out, but it was not so for them. When and if they did, they were veiled, with a white sefsari in the Tunis region that graciously covered their body while at the same time, sparing them the trouble of worrying about what they wore underneath. Their very windows were made so that they could not be seen from the street. Some women however, were lucky to have an open-minded father, brother or husband; they had private tutors at home and decided they could help others (Arfaoui, 2007).

\section{BCHIRA BEN M'RAD'S STRUGGLE FOR INDEPENDENCE AND FOR WOMEN'S EMANCIPATION}

BBM was one of those lucky women. She was the daughter of Salouha Belkhodja and Mohamed Salah Ben Mrad, a Hanfi Islam Sheikh, from a bourgeois, conservative family. She was sent to a Quranic school (kuteb) when she was five and learned the Qur'an by rote. She was hardly ten years old when her mother died. A well-learned and openminded man, her father wanted his four daughters to be educated. He taught and empowered them to be curious, to read and learn in spite of his brother's opposition. Bchira and her sisters did just that although their mother had been very traditionalist. Curiously, however, Sheikh Ben Mrad stood in severe opposition to Tahar Haddad's thesis in a book entitled "Mourning Haddad's Women6" in 1931, although he agreed that the latter's views were not against

\footnotetext{
${ }^{6}$ In an article written on 13 August 2015, Moez Karoui, nephew of Bchira Ben Mrad used the same title «Al Hidad âla imraât Al Haddad" to justify the real reason that led Sheikh Mohamed Salah Ben Mrad to stand against Tahar Haddad, reminding of the political situation under the French protectorate. Indeed, the French authorities missed no opportunity to humiliate the indigenous population. They organized a big event around the theme of "the Resurrection of Christian Africa" for they wanted Tunisia to become a land of Christianity. A procession of young Catholic crusaders wearing the uniform paraded in the streets 
Shari'a. Haddad advocated for women's rights to education and work. He was against the veil, polygamy and unilateral divorce. Exiled by his peers for his too modernist views, his academic degree was withdrawn and he was condemned not to use his title of notary any more. He died in utter poverty and it was only much later on that his memory was rehabilitated and identified as the first voice of liberation for a "modern" Tunisia and that his ideas become considered to be at the heart of the Code of Personal Status (Jelassi, 2007).

BBM's life was centered on independence and women's rights at a time when it was not easy to change the way of life so strongly ruled by a rigid and strict mentality. Indeed, it did need curiosity, courage, patience, a sense of innovation and endurance. BBM had all those qualities. At 17, she was already thinking on how to improve not only her own life, but that of the other women, as she knew there were many who suffered from the restrictions imposed on them that impeded their development. Sheikh Mohamed Salah Ben Mrad felt it his duty to teach his daughters himself and give them the best education possible. BBM spent one year at Rue du Pacha School but she had to leave it because her uncle disagreed with girls' schooling. In compensation and against his brother's will, Mohamed Salah Ben Mrad provided his four daughters with the best tutors from the Zeituna Mosque who taught them "fikh" (philology), grammar, arithmetic, as well as Farabi's logical reasoning and syllogism. Her grand-father, Sheikh H'Mida Ben Mrad, a mufti and teacher of logic at Zeituna, taught the girls Farabi's logical reasoning and syllogism. He gave them private lessons in winter at their house in Tourbet el Bey and in summer at their home located in Sidi Bou Said. BBM was excellent in Arabic, she liked poetry and learned writing. She obtained her "Certificat d'études" she reports, 3 days before her husband (Nissa, 14). She gave conferences that were published in her father's "Shams El Islam" (Sun of Islam), founded on 14 March 1937. On its first issue, the article she published was entitled "Ta'un el mara wa el rajul" (Men and women assist one another) whose main idea is the following: "women must rely on themselves to improve her status and condition."

In another article entitled "Allamu el mara' in shiitum el izza wa el hayet" (Educate women if you want dignity and life), she declares that Muslims have agreed that all that God Almighty has imposed on his creatures is that, men and women alike have the same human, social and religious rights. They must do their prayers, give alms, obey God and His Prophet and educate their children in the love for their country. The problems encountered by Muslims in this world are caused by the non-observance of the rules of Islam. Muslims have to go back to the true teachings of their religion and women play an important role in that. This is why BBM's message was "Teach women if you want dignity and life" (Chemmam, 49-51).

On 20 November 1938, BBM published on her own newspaper, “Tunis el Fatet" (n³) an article entitled "Women and education" in which she declared her satisfaction to see that Tunisian women had become modern and able to supervise things because they understood all that relates to their country. Lawyer Tahar Snoussi reported on her fund-raising activities in his book "El Mara" (The Woman) published in 1969. The winter of 1932 had been particularly rude, causing floods and desolation. An event was organized on 20 February 1932 at the home of the Khalsi family, before the women's association was founded. It was a great success that was reported as such by the various French and Arabic newspapers. Women held several women-only political meetings, at Sidi Bouriga in Hammam-Lif, at the mosque of Sidi Bou Said, at Sidi Abdelaziz mausoleum in La Marsa, and also at Manoubia Mausoleum in Montfleury. The meetings were held to encourage husbands to boycott French products, and in particular monopolies' products. According to historian Mustapha Kraiem, it was only in September 1934 that the police reported on the first feminine association that had a political character: "The Society of Muslim Ladies" founded in 1932. The women who met there assessed their desire to put an end to their seclusion so as to take part in public life. French civilian auditors reported that women participated in the struggle for independence "according to original modalities and original forms." BBM explained her involvement in politics as being the impact of her father's alienation of the West. By the same token, she justified her father's stand against Haddad as being motivated by his patriotism acting against the threat of the Westernization of Tunisian culture:

...it was my father that instilled in me the love for my country, encouraging me as well as my sisters, to take part in the struggle for national liberation and women's emancipation...

And she adds:

of Tunis...Haddad had a good friend among the Christians, Father Sellam, and Sheikh Ben Mrad believed that he was the one who had written the book and not Haddad. Adopting Haddad's reformist views then was not seen as appropriate. Bourguiba was to do the same when he encouraged women to remain veiled to stand out against the Western way of life. It was after independence that he urged women to do the exact opposite: to get rid of the veil. 
At the time of the colonization, my father considered women to be the last bastion against colonization. In no case could Western culture be allowed to weaken or assimilate it. He wanted women to take part in the combat against the French. It is for this reason that he allowed me and my sisters to go out in the street and demonstrate, to attend political meetings with the political leaders. ${ }^{7}$ (Cited by Marzouki, 38)

In that double combat she was involved in, she expressed her support for her father's criticism of Haddad: "We

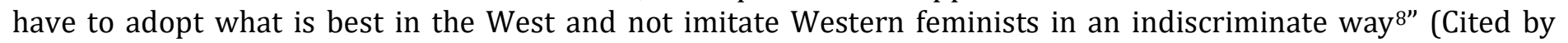
Marzouki, 82). She declared her father believed Haddad's thesis was the outcome of Western influence, and so, only "a mirror of the West."

Treating Islamic family law as a sign of distinctiveness from the French colonizer, most Tunisian nationalists of the earlier period agreed that reforms should be postponed until they could be made a sovereign state. (Charrad, 215)

BBM never hesitated to take action and encourage women to do the same. In 1952, she made an interesting statement against the veil, presenting it as less secure than religious education and good morals:

I say that religious education and morality, based on solid foundations, provide young Muslim ladies a security that is more efficient than that of the veil protecting them from any accident. The current conditions in which the country is are those of a renaissance....and it is necessary that we should be seen unveiled. We are too much absorbed by the combat for our movement and for this renaissance to deviate our attention on concerns of such a material order as that of the veil and that we should stoop to pettiness to which the lawyers of the veil for modern women ${ }^{9}$ are calling for. (Marzouki, 80)

On 5 October 1934, in Moknine, a hurried crowd, howled for their life while women screamed angrily. Window panes broke down, screams could be heard, doors were broken open, (Borsali, 2006:15), there was panic everywhere.

BBM attended several meetings in different cities, speaking mainly on women's education and emancipation, never failing to make references to the Qur'an wherever it related to women. She spoke at an event organized by the "El Akha el Kairawani10" (The Kairawanian Brotherhood) with the participation of Sheikh Mokhtar Ben Mahmoud where she spoke about women's status in the past when women were deprived of every right as well as of freedom. They could only live under other people's good will. She explained that unlike people's belief, Islam gave women the same rights as those granted to men (Chemmam, 56). She spoke at a reception honoring North-African Students and also at Mr. Uthman Al Kaak's in Sidi Bou Said. She also gave a speech to honor Tawhida Ben Cheikh-who had graduated in medicine in Paris the previous year--on 18 April 1938. She collected funds that were used to help Tunisian male and female students. In 1969, Maître Tahar Snoussi reported on the help provided by BBM's fundraising following the floods and heavy damages caused by the heavy rains that had fallen in the North of Tunisia. Indeed, the charity concert at the Khalsi's home and the funds collected helped them alleviate the sufferings of the victims. Thus, Chammam reports (p. 35), Tunisian women were able to see the significance of their role in their society, as the media of the time did not fail to report. They also learned that more could be achieved if more women were educated to take part in the development process of their country.

On 6 March 1938, BBM celebrated the tenth anniversary of the foundation of the Association of North African Students, expressing her pride and satisfaction at women's achievements for their country and for their fellowcitizens, not forgetting the help provided to the youth studying abroad. She repeatedly declared that no nation could develop without the full participation of its men and women together. She was able to convince an increasing number of women that their participation was indeed a must. Addressing the ladies attending the conference, she insisted on the fact that there could be no happiness in this world without education and work, highlighting the significance of the work of her Association in its combat against illiteracy and ignorance (Jahel). "The Association has created a library, and a club for people to get acquainted; it has created a restaurant so that people who find themselves in that country do not feel as exiles or lonesome" (Chammam, 43).

BBM also lectured on the importance of having men and women help one another. One of her articles was: "Women must rely on themselves to improve their status." It was published in $\mathrm{N}^{\circ} 1$ of her father's Shams Al-Islam

${ }^{7}$ Cited by Marzouki by an anonymous writer: Bchira B. Mrad, la femme que les terroristes français voulaient tuer, Réalités, $17 / 8 / 84, n^{\circ} 42$.

${ }^{8}$ Ibid.

${ }^{9}$ Marzouki, 80.

${ }^{10}$ Chammam, 56-60. International Journal of Research -GRANTHAALAYAH 
newspaper on 14 March 1937 (Chammam, 30; 45). In the first issue of her own review, on April 1, 1938, she wrote the following article "Tunes el Fatet and Fatet Tunes" (The young Tunisia and the young Tunisian woman) in which she declared how much she enjoyed announcing good news: the name of her review predicted the best for girls who were to have an important role in their country while acquiring a higher status. But she added, that would be possible only if they broke away from the world of ignorance (jahl) and followed the rules of Islam so as to be able to educate their children and instill in them the sense of duty toward their country (Chammam, 53).

BBM dealt with the role of women in history when Islam was at the peak of its power. Women excelled in knowledge and culture, nationalism and devotion, which had an impact on the respect granted to Muslims. The struggle for independence was the major issue in the country, but BBM did not miss any opportunity to speak about women's rights and about the necessity to have women share in the development of the country. Asked about her activities, BBM said:

We helped the Muslim Scouts, the North-African students in France, Muslim charity associations, etc... We wanted women to help the national Movement to which we had sensitized them. When there was famine, we organized popular soups. On the other hand, we provided help (fund-raising, food-bags) to the imprisoned members of the Destour. (Borsali, 2006: 17).

BBM declared her satisfaction to see that Tunisian women had finally become aware that they had to rely on themselves for the satisfaction of their own needs so as never to be a burden to anyone. Chemmam reported that BBM's awareness of women's role in society had been progressive, starting with women's access to books and reviews from Egypt as seen earlier in this article (Brouri), and then through insertion in social literary circles of the Egyptian princess Nazli Fadhel. Mohamed Abou Al Ajfan as well as professor Mohamed Belhassen had also praised her social and cultural activities. In fact, BBM read about the West as well as about the Middle-East

\section{BCHIRA BEN MRAD FOUNDS UMFT}

Professor Mohamed Belhassen reports that, in the prime of her age and with her ideas of freedom and her many activities and centers of interest, she was ahead of her time. She fought against ignorance and archaic habits and that led her to take action to free the members of her sex who were deprived of education. She wanted Tunisian women to live their time and the modernity of their age so as to learn, get an education, work and be useful to their society. She considered it necessary for women to be educated but also always to know about their religious duties (Chammam, 25; Nissa, 14)

"A woman must be educated and know about her religious duties," she wrote.

One of her articles is entitled: "Teach women if you want dignity and life ${ }^{11 "}$ (Marzouki, 81). It explains that under-development is the consequence of people's failure to observe religious precepts but also of the state of ignorance and illiteracy in which women have been maintained. Islam, she insisted, was favorable to cooperation between men and women if a general decadence is to be avoided (Marzouki, 81). BBM had many skills: a lecturer, an excellent cook, a piano player, she also knew how to embroider and excelled in most of the things. She wanted to be an example to her women fellow citizens and showed them that she had all those skills required of women and she also showed them that she talked with men while remaining virtuous and of course, that they should do the same.

Her second article: "A woman's life is at home and she must have a religious and national education ${ }^{12 "}$ presented a solution to the debate between those who were favorable to a Western education and those who had rather follow the example given by oriental feminists. She claimed that Islam was favorable to women's education without ever stating women should abandon their home. Therefore, she added, women should be granted a training compatible with their duties. "First, they have to be given a religious and national education, notions of home economics and rudiments of sanitary prevention, so as to fulfill their duty of homemakers..." (Marzouki, 82). Her third article was published in "Tunes el Fatet" and was entitled "Women and education. In 1952, she wrote "Feminine Renaissance in Tunis ${ }^{13 "}$

${ }^{11}$ Cited. Bchira Ben Mrad. 1937. Instruisez la femme si vous désirez la dignité et la vie (in Arabic), in Shams el Islam, 1356 H, $\mathrm{n}^{\circ} 5-6$.

${ }^{12}$ Cited by Marzouki. BBM: Women's life is at home and they must have a religious and national education (in Arabic), Shams el Islam, $1356 \mathrm{H}, \mathrm{n}^{\circ} 3$. (1937)

${ }^{13}$ Feminine renaissance féminine in Tunis. (in Arabic), in El Mostamaa el Arabi, March 1952, nº 12. International Journal of Research -GRANTHAALAYAH 
In 1936, keen on improving the lives of women who, she knew, were increasingly looking for knowledge and action, and with the support of her father, set on devoting her life to women's rights, she founded UMFT (Muslim Union of Tunisian Women), the first in Tunisia and the second in Africa and in the Arab world. BBM was to chair that organization until its "dissolution by Habib Bourguiba at independence. Her three sisters were members with her: Hamida Zahar (Secretary General), Nejiba Karoui, Essia Ben Miled and Om Heni Ben Mrad. Distinguished ladies were also members of the permanent board, Dr. Tawhida Ben Cheikh, Badra Ben Mustapha, Nabiha Ben Miled and others.

BBM drafted its statute and stated its three main objectives:

1) Give women the opportunity to know one another;

2) Educate girls according to Islamic morals;

3) Promote Arab Islamic culture among women.

All of these things were accepted with benevolence for they anchored the belief that society would be saved thanks to women educated in the rudiments of Islam. The leaders trusted that they would raise generations of good Muslims and therefore, granted them their full support in their activities. However, the latter were always first presented to them for approval, a process that continued under both Bourguiba and Ben Ali, hence the term "state approval feminism" attributed to Tunisian feminism. In any case, if girls were allowed to go to school and have an education, Islamic legislators never meant there would be equality between men and women. Not surprisingly, men were the ones that had both education and jobs.

BBM took her inspiration from the Egyptian Huda Shaarawi and read the newspaper she had founded, "AlMassriya." She also admired the Tunisian princess Aziza Uthmana for all the social work she had done. She used to say that women had to be educated for a country cannot develop when half of its population is illiterate and ignorant, a statement used later on by Habib Bourguiba to justify his decision to provide for girls' education and participation in the workforce, and earlier still by Kemal Ataturk in Turkey. During 25 years of relentless fighting against ignorance and illiteracy, although her main concern was the independence of her country, BBM spared no efforts to provide for the education of girls and boys as well and so, she collected money for the ones and the others. She would write about how she wanted to devote her life to the people of her own sex. BBM and the other activist women who had founded other organizations ${ }^{14}$ had opportunities to establish contacts and acquire knowledge as well as training from other women they were able to meet, for example when they attended an international Women's Congress in Paris, the Women's International Democratic Federation, on May 26, 1945, following which, March 8 became Women's Day from 1946 to 1952 in spite of strong opposition from the French authorities. Colonial oppression being a major cause of concern made Bourguiba demand that women should continue to wear the veil so as to enhance Tunisian culture in opposition to that of the colonists. On 8 January 1929, attending a conference given by Habiba Menchari, a young unveiled woman advocating for women's emancipation, Bourguiba had presented a counter argument, urging women to wear the veil not to lose their identity and to cling to their customs, traditions and culture in order to protect their national identity from amalgamation with that of the colonizers ${ }^{15}$. In fact, both in 1924 and 1929, Manoubia Ouertani and Habiba Menchari were to be severely criticized by the Destour for their opposition to the hijab and men's ensuing domination over women (FTCR). Indeed, women's emancipation was seen as assimilation of the colonizers' culture and therefore, detrimental to the Tunisian identity and culture.

Like Sheikh Ben Mrad's, Bourguiba's attitude did not reflect his real position which was for women's emancipation and therefore against the veil which he was later on to compare to "an odious rag" but it was a form of resistance to colonialism.

\section{BCHIRA BEN MRAD BECOMES AN ACTIVIST AND FOUNDS THE FIRST FEMINIST ORGANIZATION}

\section{"Women have to mark their contribution in life, they have to be given a useful religious education to be able to bear and keep the pledge granted to them by God" (Bchira ben Mrad)}

${ }^{14}$ L'Union des femmes de Tunisie (UFT) was founded in 1944, as the Germans were leaving Tunisia, before even the end of World War II. Most of the members of that organization were communists. Among their many activities, they joined the Committee for Peace. The main goal of these women activists was to make women aware that they were a power that could take its destiny in its own hands (Borsali, 18).

${ }^{15}$ Wikipedia. Habib Bourguiba, in https://en.wikipedia.org/wiki/Habib_Bourguiba

International Journal of Research -GRANTHAALAYAH 
BBM had a level of education high enough for that time to develop an interest in the situation in her country and to acquire knowledge about it. In an interview with Noura Borsali realized shortly before her death (1993), she reported that her interest in politics started when she was 13 or 14 when she overheard a conversation at a meeting in Sidi Bou Said among national prominent leaders such as Mahmoud El Matri, on the disastrous impact of colonialism on the country and learned about repression and the humiliations inflicted on her fellow-citizens (Massy, 16). National leaders were either in exile or in jail. Women were no part of the National Movement for independence then and action was needed. She started to write in her father's newspaper, Shams Al Islam founded on 14 March 1937. In the first issue, she wrote that "men and women need one another" (Chammam, 30) and continued to develop this assessment in the 8 following issues. She founded her own newspaper, Tunes el Fatat (The Young woman of Tunis) in 1938, in which she provided support to Tunisian nationalism and women's emancipation; she also answered the criticisms made by the Zeituna sheikhs who strongly objected to her feminist projects. "She was a thinker," Sonia Ben Mrad, a relative of BBM and member of the Bchira Ben Mrad Foundation said at a press conference organized on the celebration of her one hundredth anniversary on 21 November 2013 in Tunis (Massy, 17). Well-read, she knew about the situation of women in other countries, in particular Turkey and Egypt and read regularly Al-Massriya, founded by Egyptian Houda Shahraoui (Massy, 16). Her prior goal was to help in the decolonization process, but she was convinced that they first had to overcome their underdevelopment, and also, an issue she never stopped insisting upon: that they would not succeed in doing that without women's participation. She started to think of ways to act and of strategies to adopt to improve women's status. Like male reformists, she claimed that her fellow citizens did not understand the Qur'an properly for, she explained, the Qur'an never says anything against women's education, making use of the ideas of $19^{\text {th }}$ century thinkers and reformers. Indeed, she learned from them as well as from her male peers a basic understanding of her country's political situation and of women's status. She was able to transmit all that she had learned to her female fellow citizens, and she took pride in the increasing number of women activists. She encouraged young girls to discard the veil and wear coats in the winter time and mid-calf skirts and offered them the possibility to travel. She cooperated with the Union of Tunisian Women (UFT), founded in 1944 and whose members were mostly communists, like Gladys Adda, Neila Haddad, Sofia Zouiten and Nebiha Ben Miled, among others.

The feminism that appeared in the 1920s and 1930s was based on education and included a number of educated women. Tawhida Ben Cheikh16, Badra Ben Mustapha, first Tunisian nurse, Nabiha Ben Miled, Radhia Haddad who was to be for a long time president of the UNFT, Association of Tunisian women founded by Bourguiba and Fathia Mzali who took over after Radhia Haddad was dismissed by Bourguiba for disobedience. The meeting BBM organized on 18 April 1937 to pay tribute to Dr. Tawhida Ben Cheikh was a great opportunity to sensitize women to the significance of education. She said:

Ladies, this is indeed, one of the happiest days for Tunisian women. Today, women can raise their heads. Women have embarked on the road to greatness and regard. They have proved that no obstacle could prevent them from moving ahead... This doctor knew what God expected her to do. Seeking knowledge is a religious duty for every Muslim man and every Muslim woman. This Tunisian doctor chose to live in exile in order to fulfill her religious duty. She left her family and country to solve the great problem of the absence of Muslim female doctors, to do her duty for the daughters of this country. ... this female doctor has come back to us with her head proudly raised, proving that, if they really want to work, Tunisian women can be successful and acquire the knowledge they wish for; nothing will stop them, neither hardships nor hard work. (translated by Arfaoui, 2009: pp.155-156)

Tawhida Ben Cheikh answered her by declaring that she considered it her duty to have chosen to become a medical doctor and she urged the ladies attending the meeting to send their daughters to school so that they would, like herself, help their society. Tawhida Ben Cheikh was, indeed; going to be of great help for in those days, men could not accept to have their women examined by men and there were no female doctors! So, it is easy to imagine she had her hands full, being the single female doctor in the country!

If women were not quick to respond to her invitations at first, her insistence bore fruit in the end. Branches were formed in the other cities, reaching out an increasing number of women throughout the country so that the

${ }^{16}$ Tawhida Ben Cheikh was to be for a long time the only female doctor in the country. Today, $60 \%$ of the Tunisian medical doctors are women. See Bchira Ben Mrad's speech honoring Dr. Tawhida Ben Cheikh translated by Khedija Arfaoui in Women Writing Africa: The Northern Region: p. 154-156. 
movement was not particular to the city-capital ${ }^{17}$. She collected money for the construction of schools for girls. That was not all for she also thought of the number of boys who were eager to have a higher education but did not have the means to do that. And so, she collected money for them too. A number of young men owe their higher education success to her endeavors. She would send them food and money.

BBM kept letters from those students, asking for her help without which they would not have been able to continue their education in France "Mama Bchira, send me some money so that I can pay for the rent of my room," one wrote, or "if you do not send me money, I will have to interrupt my studies..." wrote another. Most of those students were to become the elite of the country, as ministers and leaders from the Destour, people like Jallouli Fares, Mongi Slim, Rachid Driss, Habib Bourguiba, Behi Ladgham,, Ahmed Ben Miled, Slaheddine Bouchoucha, Mongi Baly, Mohamed Belhassine, Sadok El Mokaddem, Chedli Klibi and Hedi Nouira later on.

BBM also provided scholarships for poor girls. How did she manage to do that? She was an excellent observer and did not miss any opportunity to learn. For example, when she heard that activists from the Destour party had organized a fund-raising fair in order to help Tunisian youth go and study in France, she decided to organize one as well and obtained the agreement of two great political figures, Ali Belhaouane and Mongi Slim. A committee was formed and they were able to have thousands of women get together. The more women came, the more money they could collect for their different projects. The fair was a success: a huge amount of money was collected and given to the leaders of the Destour for the benefit of Tunisian students. The experience was very encouraging. The Union of Muslim Women was founded a few days later (Kais Ben Mrad; Borsali; Chammam), in 1936. It was solidly tied to the Destourian Party, its activities following instructions and information from its leaders. Habib Bourguiba started visiting them regularly for he approved of their activities (Borsali, 17). Women's presence could be felt and seen as women went out of their seclusion and marched in the streets, holding the Tunisian flag and singing the national anthem together with men. They held actions against colonialism and organized conferences and seminars with the media reporting on them, publishing the conferences given by some of the most prominent women (Maalej). Such activities were bound to displease the colonial powers. BBM received threats from "La Main Rouge" (The Red Hand), a French terrorist group that sought to curtail the Tunisian nationalist movement and was responsible for the assassination of Farhat Hached ${ }^{18}$, Secretary General of the General Union of Tunisian Workers (UGTT) on 5 December 1952. She was also severely criticized by the conservative branch of Zeituna and the colonial powers often curtailed her activities. It was for this reason that her association had to wait until 1951 to be granted a visa (Massy, 17).

1935 was a year of political effervescence but BBM felt frustrated at the absence of women. That developed in her the feeling that women had to take part in this struggle for independence. Several prominent politicians had been arrested and held in exile out of the country. Women's mobilization was crucial for it raised awareness and encouraged action. Several women criticized her for doing what they considered unwomanly actions. She invited 1500 women, but only a few came and: "they [only] came to blame me," BBM reported bitterly in 1952. It was not easy to change the mentalities. At one event, her father had asked his wife to meet friends who were to come for a visit. She refused and could not be made to change her mind. The reason was simple: she could not meet men she was not related to because that was the way she had been brought up. To her, the men she could meet were only her father and her husband! It was as simple as that!

To avoid conflict with the colonial powers, BBM organized her meetings in homes, presenting independence as her major issue, claiming rights stated in the Qur'an, the religion connotation made the organization more acceptable as there already were Christian and Jewish organizations. "We did not speak about women's rights because we were right in the middle of national liberation. Our major concern was the independence of the country," she said (Bakalti, 16)

\section{BCHIRA BEN MRAD AND WOMEN'S RIGHTS}

Deeply involved in the nationalist struggle, BBM did not forget her main center of interest: women's rights. But the fight against colonialism was a great opportunity to get women to assemble, meet other women, know each other

${ }^{17}$ Just for comparison, ATFD and AFTURD, the two autonomous feminist organizations founded in 1989 were never able to create branches in the other cities under Ben Ali.

${ }^{18}$ Bchira Ben Mrad also had contacts with Farhat Hached who gave her his full support in her endeavors and activities. Farhat Hached was a Trade Union leader (UGTT). He was assassinated by “La Main Rouge” on 5 December 1952.

International Journal of Research -GRANTHAALAYAH 
and establish links. She sensitized women to the right to vote, encouraged meetings of men and women, together at a time when meetings for both sexes were not tolerated. And it is important to say that, because she belonged to no political party, she represented early civil society in Tunisia. Dr. Sonia Ben Mrad said about her that she was "... a 'thinker," a woman who created a coherent and enlightened thought around women. A strong woman who had never been afraid, who never stepped back in spite of intimidations, for example a bomb was placed in front of her home but fortunately, it did not explode (Hammam Ensa, 2013). She encouraged women to travel, discover the world and develop their personalities. She kept her maiden name according to the Muslim tradition and did not adopt the European usage of taking the husband's name, which the generations of the sixties on were to adopt. The activities she organized were cultural, scientific, social and political. They helped other women, the Muslim Scouts, the North African students studying in France, Muslim charity associations, life-saving associations, and others. Gradually, women were sensitized to the National Movement for independence and did not spare efforts to help. They were quick to provide help when there was famine and offered popular soup to fight off hunger. They visited political prisoners and brought them food, money. All the while, BBM expressed the need to educate women as a major asset to eradicate under-development, illiteracy and ignorance, stressing the fact that it was wrong to believe Islam banned girls' education. BBM said, however, that considering the fact that they were closely watched by the colonial powers, they generally avoided speaking about women's rights. Still, issues like men and women equality in politics, the right to vote for women, co-educational schools were major topics of discussion. BBM ignored the Bey's and the colonizers' opposition to her educational program for girls. She often had to show up at the police station to be interrogated. She was even arrested. At the large political meeting of 8 April 1938, she stood, veiled next to Ali Belhaouane who was giving a speech about the need to have a Tunisian nationalist government. On the next day, 9 April 1938, the French authorities gave the order to shoot: one hundred people were killed (Mariem).

Indeed, they had taken strong stands against the colonizers, they had marched, defying the colonial powers, they had been jailed and, BBM had taken a strong position against the belief that women's place was the home, claiming that the Qur'an was not understood properly. She was able to have women involved in public life. She made them take stands against the colonial powers (Massy, 17).

The first political meeting took place at BBM's in 1936. Its impact is not to be ignored for, following that, several women attended the meeting where Bourguiba reported on the national claims decided by the Party. Women's activities in the Destour against colonization increased, drawing the colonists' anger: protests in front of the General Residence on 8 April; again on the next day, they were claiming constitutional guarantees. On 11 April 1938, women also took part in protests in Tazarka. Quoting Souad Bakalti, Borsali reports that activities against the colonizers continued in the shape of conferences for example. Or they would meet in the most unusual places in order not to attract attention. At first, they would meet in the Zaouia of Sidi Brahim (Secrétariat d'Etat, 10). Then they met in hammams, homes, zaouias (different shrines the Muslim populations liked to go to pray but also to make wishes, in the hope of finding a husband/wife, to become pregnant for a woman, to recover from a disease...). They went to hospitals or wherever they could meet without attracting the attention of the police (Borsali, in Realités, 21). Other protest marches took place in December and January 1939 at the arrival of official visitors from France. To reassure the colonizers on their good intentions, they started by welcoming the visitors and ended their demonstration by claiming their Arab-Muslim identity and demanding the release of political prisoners. As a result, they were jailed between 15 to 30 days. Female activism continued fearlessly, challenging the colonial powers. On 15 January 1952, continuing their protests against repression, they marched in Beja. They were sentenced by a tribunal in Bizerte, between 3 to 6 months suspended sentence. On January 20,34 other women were arrested. 1952 was a year when women were particularly active and several of them were arrested or deported in 1953. BBM was among the deportees (Marzouki, 163-164). Women continued to act and they visited the women activists in jail, providing them with the supplies they needed. The Destour created official female branches that were to play a significant role. For example, in October 1951, 400 women with their children assembled in front of the Direction of National Education. Their demands were essentially political: they wanted Arabic to become the working language instead of French and protested against the fact that a number of girls were left out of school ${ }^{19}$.

Also, on 15 January 1952, about 800 people met in Beja headed by 8 women belonging to the Destour. Bourguib recognized women's participation in the struggle for independence although he did not mention BBM's:

${ }^{19} \mathrm{http} / / /$ www.africaciel.com/afrique/portail/index/Mouvement_national_tunisien.html\#R.C3.B4le_des_mouvements_f.C3.A9 minins 
During the national struggle, women were not afraid to put their lives at risk, organizing political meetings here and there, defying the colonizers. Their activities did not go unnoticed and they were arrested and thrown in jail, like the other male combatants. Their courage commanded men's respect. Women took part in demonstrations and faced bullets. A woman was even killed in action in Teboulba ... (Secrétariat à l'information, 10)

\section{BCHIRA FALLS INTO OBLIVION}

BBM thus played a significant role in different sectors, but mostly in the struggle for independence and in women's emancipation. What did she get in return for her achievements? Interviews given by BBM after independence reveal a woman who is disappointed and bitter for having been forgotten by all those she had striven to help. Many of the men who held important jobs in politics and elsewhere owe her their success as seen above. She had done so much for them, providing them with the money they needed to pay for their rent and their food. When the money she had collected for them was not enough, she used her own money. There was also a lot of resignation to her lot, which she believed, was all that God had set out for her (Hatem el Karoui, 2013). At independence, Bourguiba founded the National Union of Tunisian Women (UNFT), regretfully, never acknowledging the work done by BBM not even inviting her for the celebrations of 13 August, Tunisian Women's National Day. No mention was made of her name. “... her entire combat was erased from the Tunisian people's collective memory by Bourguiba, as if she had never existed!” BBW had no choice but to step away. Here is the explanation she gave Ilhem Marzouki in a private interview:

After having been President of this organization during twenty years, it was too humiliating for me to feel myself degraded in occupying any kind of position in the new Union, for I have been raised in the sense of dignity and selfrespect. (Marzouki, 77)

Why was she so humiliated when we know that Bourguiba used to go and visit her? He would write to her from France, his first wife Mathilde used to visit her as did his second wife, Wassila Ben Ammar later on. He knew about all that she had done to help and support the Destour and young Tunisian students studying in France. He even called her "Um Tunes" (the mother of Tunisia) as Dr. Sonia Ben Mrad reports. Even Selma Baccar's film, "Fatma 75" realized in 1976 about the development of women's status in Tunisia was censored without any explanation. A fiction documentary, the film introduced three generations of women: 1) 1930-1938, with the foundation of the first women's organization; 2) 1938-1952, with the links between women's struggle for recognition and the struggle for independence; 3) 1956-on, the CPS, the Tunisian family code and the changes it brought into women's lives. The film was simply censored. It is difficult to comprehend how, strong feminist as he indeed was, Bourguiba could censor a film about women's empowerment. Selma Baccar had her own explanation as she said that it was his egocentrism that had made Bourguiba refuse to accept the presentations of BBM and Tahar Haddad as initiators of the feminist movement. Bourguiba became thus:

... the one vested with the decisive authority in terms of State affairs and society. He will be the one responsible for making and breaking all the people of authority around him. But he is also the one who will be responsible for ensuring a vigilant and relentless control with the objective of checking the subordination of all the organisms of the State to his policy and to annihilate the appearance of any pressure dissident group. (Marzouki, 153)

That was probably one of Bourguiba's greatest weaknesses: he had to be the initiator of every positive achievement made in the country. It was only on 1 December 2013 that extracts of the film were presented on the celebration of BBM's one-hundredth birthday at the National Theater in Tunis. BBM had been a strong actor for independence and women's empowerment, reaching out to women all over the country. But, the official message attributed the title of "initiator of the feminist movement" to Bourguiba as we can see below:

The distinct honor to have been at the origin of "Tunisian women's liberation" was to the credit of President Bourguiba. This personal glory was implemented by the promulgation of the Code of Personal Status hardly a few months following independence. (Marzouki 158)

This point is made clearer in Bourguiba's 1976 speech:

The emancipating laws promulgated in their favor have spared Tunisian Women the pain of wearing themselves out in advocacy struggles which women in most countries have had to undertake, enabling them to get on right away with at the apprenticeship of freedom and responsibility ${ }^{20}$. (cited by Marzouki, 158)

${ }^{20}$ Habib Bourguiba, at the 6th Congress of UNFT, Monastir on 13-15 August 1976.

International Journal of Research -GRANTHAALAYAH 
Because this initiative had been "a reform from above," and not from a movement initiated by women, it became currently known as "state feminism."

BBM had provided significant support in two of Bourguiba's goals: independence from France and women's emancipation. Called the "Mujahid el Akbar" (the Greatest Mujahid), Bourguiba did not want anyone to share those achievements with him. However, if BBM used to lead a comfortable life at her father's and also at her husband's, regretfully, she ended poor, living in a poor neighborhood, and forgotten. In a way, like Tahar Haddad. She lived in an old, rundown palace known as "Dar el Bey" (the Bey's House) located at the foot of the Boukornine mountain in Hammam-Lif. She, her adopted son and his parents shared a floor.

On 1 December 2013, her name resurfaced when Tunisia celebrated her $100^{\text {th }}$ birthday. It is often stated that Bourguiba offered Tunisian women rights on a silver tray. There is no doubt whatsoever that he was instrumental in legalizing women's rights. However, even though many of the discriminations inflicted on Tunisian women were at last eradicated with the promulgation of the CPS, as we have seen in the first part of this article, women had not been strangers to it.

"It is true that Bourguiba was for women's emancipation, but the rights that were granted to women in 1956 never were a gift offered on a silver tray. It is women's precious participation to the struggle for national liberation that provided for the acquisition of these rights," BBM was to declare.

"The woman question had never been among the main issues of the Neo-Destour before 1956..." (Marzouki, $164)$ and it remained unclear during the period preceding independence (1954-1956). At the same time, women branches of that same and unique party were founded in such towns as Tunis, Bizerte and Beja between 1951 and 1952. It was when the big issue about whether women were to be allowed to take part in the legislative elections that the woman question came back. All of the women involved in organizations agreed on the fact that "if illiterate men can vote, Illiterate women must have the right to vote too" and, "if they are voters, women must also be eligible, exactly like men, according to their capacities" for, Md. Dr. Tawhida Ben Cheikh declared, elections are not a science business but one of awareness. ${ }^{21}$ BBM was pleased with women's achievements:

Tunisian women have made progress and raised their level of reflection; they are now able to manage their environment, express their preferences, bewail, enjoy and disapprove and they understand the situation of the country from every angle. They take part in the charity, social and scientific associations' activities. I am pleased with all of this and I sometimes hear disturbing things like marriage proposals and things like that. (Hammar)

B. B. Mrad never failed to express her point of view about important issues. At the same meeting as the one above when Tawhida Ben Cheikh said what she thought important about elections, she dared demand from the government that women take part in the coming elections just like men. In 1957, Tunisia became the first country in the Arab world to grant women the right to vote. Several scholars think a collective effort must be done, especially for People to enjoy doing just that: giving Bchira Ben Mrad the homage that she is entitled to. BBM died on 4 May in 1993.

\section{SOURCES OF FUNDING}

This research received no specific grant from any funding agency in the public, commercial, or not-for-profit sectors.

\section{CONFLICT OF INTEREST}

The author have declared that no competing interests exist.

\section{ACKNOWLEDGMENT}

None. 
Khedija Arfaoui

\section{REFERENCES}

[1] Antoun, R. T. 1980. The Islamic court, the Islamic judge and the accommodation of traditions: A Jordanian case study. International Journal of Middle East Studies, 12: 455-467.

[2] Arfaoui, Khedija. 2007. The development of the feminist movement in Tunisia 1920-2000s. International Journal of the Humanities, volume 4, number 8.

[3] Arfaoui, Khedija. 2009. Bchira Ben Mrad Honoring Dr. Tawhida Ben Cheikh. Eds. Fatima Sadiqi, Amira Nowaira, Azza El Kholy, and Moha Ennaji. 2009. Speech translated from Arabic into English by Khedija Arfaoui. In: Women Writing Africa: The Northern Region. The Feminist Press, New York: pp.154-156

[4] Bakalti, Souad. 9-15/3/2006. Bchira Ben Mrad: Notre préoccupation première était l'indépendance de notre pays. Réalités. N 1054:16-17.

[5] Barbouche, Moncef. 12 May 2013. Cited by Hatem El Karoui in: http://maamoura.net/index.php?option=com_content\&view=article\&id=97\%3A2011-05-28-12-15-

55\&catid=30\%3Amouvement-faminine-Ben Mrad, Kais. 13 August 2013. Bchira Ben Mrad, la pionnière du mouvement féministe en Tunisie. Espace Manager. In https://www.espacemanager.com/bchira-ben-mradla-pionniere-du-mouvement-feminin-en-tunisie.html

[6] Borsali, Noura. 9-15/3/2006. Bchira Ben Mrad. Réalités, № 1054: 16-17.

[7] Boukhris, Raoudha. 2012. Al-çadâq al-kairawâni (Le contrat de mariage Kairouanais) et Al-Zawâj al-orfi (Le mariage coutumier). Multaqa A Ajial. A magazine published by the alumni of the Lycée Rue du Pacha. $N^{\circ} 59$ 60: 6-8.

[8] Brouri, Fathia. 7 March 2017. Bchira Ben Mrad, libératrice de la femme tunisienne. Hatem El Karoui. In http://radiotounsi.net/bchira-ben-mrad-liberatrice-de-femme-tunisienne-de-hatem-el-karoui/

[9] Chammam, Mahmoud. 2001. Bchira Ben Mrad, the pioneer of the feminist movement in Tunisia. Tunis: Cultural Printing House.

[10] Charrad, M. Mounira. 2001. States and Women's Rights: The Making of Postcolonial Tunisia, Algeria, and Morocco. University of California Press.

[11] De Montety, Henri. 1958. Femmes de Tunisie. La Haye. Mouton et Co. Paris-La Haye. Cited in «L'évolution de la femme tunisienne ». Tunis: Publications du Secrétariat d'Etat à l'Information.

[12] El Karoui, Hatem. 2013. Le tête-à-tête entre Lilia Labidi et Bchira Ben Mrad. In http://www.alterinfo.net/Letete-a-tete-entre-Lilia-Labidi-et-B-chira-Ben-M-rad_a93900.html

[13] En savoir plus sur http://www.alterinfo.net/Le-tete-a-tete-entre-Lilia-Labidi-et-B-chira-Ben-Mrad_a93900.html\#sPjXvXEcx47KvrMT.99

[14] FRCR. Fédération des Tunisiens pour une citoyenneté des deux rives. 20 Oct. 2009. Bchira Ben Mrad. In: http://citoyensdesdeuxrives.eu/index.php?option=com_content\&view=article\&id=587:bchira-ben-mrad\&catid=122: dune-rive-\&Itemid $=128$

[15] Haddad, Tahar. 1930-1978. Notre femme, la législation islamique et la société (Our women in law and society). Imar'atuna fi al-shari'a wa al-mujtama'a. Tunis: Maison tunisienne de l'édition.

[16] Hammam Ensa. 22-11-2013. Bchira Ben Mrad (1913-1993). In: https://www.hammamensa.com/details_articles3.php?cat_id=75\&art_id=6

[17] Hammar, Hamadi. 02/12/2013. Document: Bchira Ben Mrad une illustre femme tunisienne qui a passé toute sa vie en résidence surveillée. In http://www.alterinfo.net/Document-B-chira-Ben-M-rad-une-illustrefemme-tunisienne-qui-a-passe-toute-sa-vie-en-residence-surveillee_a86723.html

[18] Jelassi, M. (2007). Tahar Haddad, tunisien et feministe. Athétürk. Retrieved from http://atheturk.free.fr/index.php?option=com_content\&task=view\&id=299

[19] Julien, Charles-André. 2003. L'Histoire de l'Afrique du Nord: de la Conquête Arabe à 1830. Livre II. Tunis: Cérès.

[20] Karoui, Moez. 13/08/2015. Al Hidad âla Imraât Al Haddad. In https://www.facebook.com/notes/mo\%C3\%ABz-karoui/al-hidad-\%C3\%A2la-imra\%C3\%A2t-ahaddad/10154151115739115/

[21] Khaddar Zangar, Saloua. 12/05/2017. Une école pionnière, l'Ecole de la Rue du Pacha. In http://www.leaders.com.tn/article/22288-une-ecole-pionniere-i-ecole-de-la-rue-du-pacha

[22] Largueche, Dalenda (1991). Dar Joued ou l'oubli dans la mémoire. In Ahmed Mahiou and Jean Claude Santucci (Eds.). Tunis: Cérès Editions Annuaire de l'Afrique du Nord, Tome XXX, 177-190. 
[23] Larguèche, Dalenda. 2010 and online 2012. Women, family affairs, and justice: Tunisia in the 19th century. In the History of the Family. Publisher: Routledge. http://www.tandfontline.com/loi/rhof20

[24] Mariem. (2013). Les combats de Bchira Ben Mrad. In Baya, https://www.baya.tn/rubriques/society/societe/les-combats-de-bchira-ben-mrad/

[25] Maalej, Abdelkader. 2015. L'information au féminin. Edilivre. In https://www.edilivre.com/frontwidget/preview/book/id/705052/

[26] Mahfoudh-Draoui, Dorra. 2008. Rapport de genre et mariage dans la société tunisienne. In Migration Société: pp. 129 - 140. https://www.cairn.info/revue-migrations-societe-2008-5-page-129.htm

[27] Massy, Perrine. 28/11 to 4/12/2013. Une grande figure historique du féminisme tunisien. Réalités, $N^{\circ} 1457$ : 16-17.

[28] Nissa. August 1985. El Saida Bchira Ben Mrad, Raissatu ewil jamiya nissaiya tunussya (Madame Bchira Ben Mrad, President of the first Tunisian Women’s Association), $\mathrm{N}^{\circ} 3$

[29] Secrétariat d'Etat à l'Information. 1978. L'évolution de la femme tunisienne. Tunis. Imprimerie de la SAGEP.

[30] Shams el Islam. 1937. Scientific moral Muslim review. Director: Mohamed Salah B. Mrad, 1356 H.

[31] Smith, Julia Clancy. 12-2000. L'école Rue du Pacha, Tunis: l'enseignement de la femme arabe et de «la plus grande France » 1900-1914. Clio. Histoire, femmes et société. In https://clio.revues.org/186. Put on line on 24 May 2006.

[32] Tchaicha, Jane D. and Khedija Arfaoui. 2017. The Tunisian Women's Rights Movement: From Nascent Activism to Influential Power-broking. Routledge, Taylor and Francis Group, Routledge.

[33] Vincent, Rose. 3 july 1972. Les Tunisiennes ont jeté leurs voiles aux cactus. Elle, $\mathrm{N}^{\circ}$ 1385: pp.4-8.

[34] Zouari, Fawzia. September 2002. « Il était une fois une reine... » Jeune Afrique l’Intelligent. N 2177: 56-58.

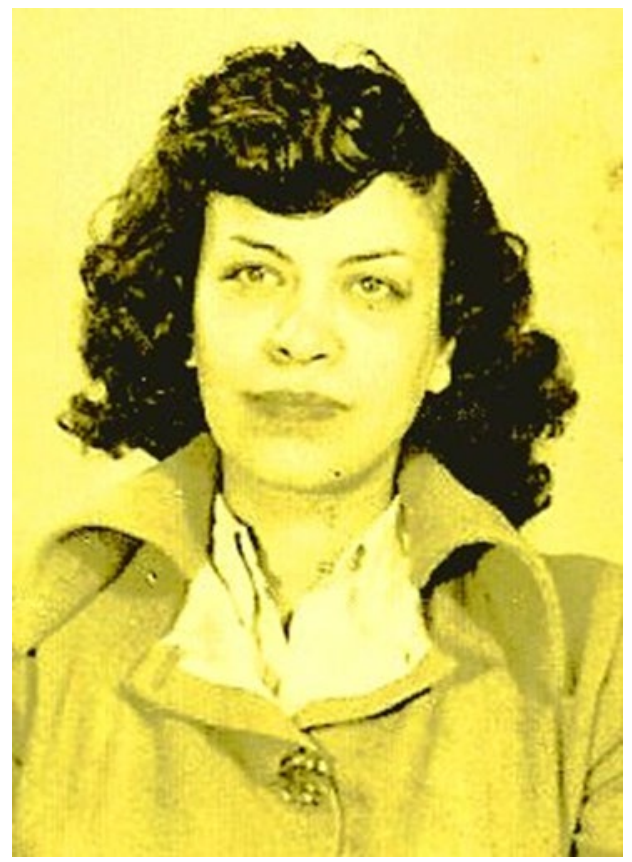

Bchira Ben Mrad, President of the Muslim Union of Tunisian Women

Source: Authorized by Moncef Ben Mrad, Bchira Ben Mrad's brother, from his private collection 